Notre Dame Law School

NDLScholarship

Journal Articles

Publications

1997

\title{
Transitional Justice in Eastern Germany
}

Donald P. Kommers

Notre Dame Law School, donald.p.kommers.1@nd.edu

Follow this and additional works at: https://scholarship.law.nd.edu/law_faculty_scholarship

Part of the Law and Politics Commons

\section{Recommended Citation}

Donald P. Kommers, Transitional Justice in Eastern Germany, 22 Law \& Soc. Inquiry 829 (1997) (book review). Available at: https://scholarship.law.nd.edu/law_faculty_scholarship/1390

This Book Review is brought to you for free and open access by the Publications at NDLScholarship. It has been accepted for inclusion in Journal Articles by an authorized administrator of NDLScholarship. For more information, please contact lawdr@nd.edu. 


\section{Transitional Justice in Eastern Germany}

Donald P. Kommers

Inga Markovits, Imperfect Justice: An East-West German Diary. Oxford and New York: Oxford University Press, 1995. Pp. ix + 204. $\$ 43.69$ cloth.

On October 3, 1990, the German Democratic Republic (GDR) ceased to exist. On that celebrated day of German unity, the GDR incorporated itself into the legal and political system of the Federal Republic of Germany (FRG). Economic and social union had taken place a few months earlier. ${ }^{1}$ After 40 years, a people who had become accustomed to central planning, full employment, and state ownership of almost everything suddenly found themselves compacted into a profit-driven market economy rooted in private ownership. Equally swift was the legal revolution, for Unity Day witnessed the toppling of the GDR's judicial system, along with its superstructure of socialist legality, and its replacement by West German judicial institutions. The hurried changeover touched the lives of all GDR legal professionals-judges, prosecutors, lawyers, notaries, and law professors. What some of them encountered and felt in the overnight shift from a socialist legal system to a capitalist one is the subject of Inga Markovits's remarkable book.

Donald P. Kommers is Joseph and Elizabeth Robbie Professor of Government and International Studies at the University of Notre Dame as well as a member of the Notre Dame law faculty. For their helpful comments on an earlier draft of this essay, the author would like to thank Peter W. Quint, Inga Markovits, James McAdams, Gregg O. Kvistad, Kim Lane Scheppele, Robert E. Rodes Jr., and Thomas Shaffer.

1. Economic and social unity were accomplished under the State Treaty on Monetary, Economic, and Social Union. The treaty was signed on May 18, 1990, and entered into force on July 1, 1990. The two German states reunited under the terms of the Treaty of August 31, 1990, between the Federal Republic of Germany and the German Democratic Republic on the Establishment of German Unity (hereinafter Unity Treaty). 
As its subtitle indicates, Imperfect Justice appears in the form of a diary that tells the story-largely through the "self-presentation of people deeply involved in the socialist legal system" (p. 3) - "of the sudden death of socialist law in East Germany" (p. 1). Markovits's diary is intended to capture "the reactions, hopes, and fears of some of [East Germany's] survivors" (p. 1) immediately before and after the GDR's collapse. The diary-like format, based on personal observation and interviews of an unstructured and nonrandom nature, is likely to be seen by some critics as its chief weakness. First, its focus on such a narrow slice of time says little about the long-range prospects for the development of a liberal constitutional order in Eastern Germany. Second, its emphasis on the personal stories of East Germans when they were most vulnerable to the vicissitudes of change tends to induce a false sympathy for persons who had been, after all, the willing functionaries of a repressive regime.

To leave the matter there, however, would devalue the real merit of this book. Markovits's lucid portrayal of the hopes and fears of GDR professionals reveals an important side of reunified Germany and, as we shall see, it has serious implications for the future of liberal constitutionalism in Germany as a whole. As for the GDR's oppressive features, Markovits allows that they "cast their shadows" over all her interviews, and she makes plain her own low opinion-even contempt-of those among her respondents who offered no apology or confessed no shame for the GDR's excesses. But she also tells us that these excesses are outside her main concern. Her interest lies rather in the normal operations of socialist law, what she describes as its "non-scandalous everyday aspects" (p. 3)—aspects admittedly ignored by most Western writing on the GDR. It is precisely this study's emphasis on the system's normality, as seen through the eyes of the persons interviewed, that stamps it with a mark of historical importance.

What also makes Imperfect Justice an important record is the perfect fit between the writer and her topic. Inga Markovits is a German-born professor of law in the United States and an acknowledged authority on East Germany and its legal system (Markovits 1971, 1978, 1982, 1986, 1996). In the 1970s she examined the GDR's "struggle to transform an inherited system of bourgeois law into a socialist civil law system" (p. 1). Now, years later, she would look into the dramatic reversal of that process and do so as it occurred. She happened to have been in Berlin shortly after its infamous Wall came down, with unification appearing on the horizon. Recognizing the importance of the moment, she arranged to spend a year in East Berlin "to sketch the last portrait of a legal system about to disappear into the belly of history" (p. 3). East Berlin was a good place to sketch the portrait, for the shock waves of dislocation caused by reunification were felt most strongly there. 
Markovits's journal begins on September 6, 1990-a month before the GDR disappeared-and ends on June 20, 1991, nine months after its eclipse. During this critical period, she interviewed judges, prosecutors, and legal scholars; observed the dismantling of the old legal system and the installation of a new one; and even played the role of a participant-observer when she was recruited to serve on a faculty committee charged with reviewing the records of East German law professors who were anxiously awaiting notice of their dismissal or reappointment. Although her daily entries focus on the discrete experiences of particular persons, they also convey a sharp sense of the formative legal context in which various legal professionals carried out their official duties.

\section{EAST GERMANY'S LEGAL TRANSFORMATION}

It will help at the outset to place Markovits's account within the larger context of institutional reform and political reorientation that the Unity Treaty prescribed for East Germany. Imperfect Justice should also be understood-and assessed-within the still larger context of the spirited intellectual debate in Germany over the meaning of the GDR's past and its significance for the future of German democracy. We may begin with a brief summary of the Unity Treaty's provisions for legal reform in the old GDR, reserving until later in this essay a discussion of the intellectual debate about the German past.

The Unity Treaty's article 13 provided that "administrative bodies and other institutions [in the GDR] serving the purposes of public administration or the administration of justice" would henceforth be placed under the administrative jurisdiction of the reestablished Eastern states, or Länder. This provision covered almost every major area of the GDR's public life, including the civil service, courts of law, prosecutorial offices, state-funded legal research institutes, and university law faculties. These institutions were now to be reorganized by the eastern Länder on the basis of West German law. In addition, the treaty called for the dissolution (Abwicklung) of administrative units rendered obsolete or superfluous owing to the required governmental remodeling (Unity Treaty art. 3 [Protokoll zu art. 13]). To soften Abwicklung's impact, employees of a dissolved unit would receive $70 \%$ of their salary for six months while waiting to be transferred to another administrative division. Because East Germany's bloated civil service would be "downsized" to West German levels, the prospect of these employees regaining employment in the public sector was, as it turned out, a forlorn hope. 


\section{The Public Service}

In reorganizing the public service in the East, the new all-German government had a delicate balancing act to perform. "On the one hand," as Peter E. Quint notes $(1997,176)$, "the complete dissolution of GDR institutions could squander or impair a generation of intellectual resources. On the other hand, retention of existing structures could perpetuate incompetence, pockets of totalitarian ideology, and the results of political favoritism." The Unity Treaty tried to do the initial balancing. Employees of retained units were permitted to remain in their posts until screened for competence and political reliability. Before receiving permanent appointments, however, they were required to undergo a three-year probationary period, whereas employees of dissolved administrative units were likely to have their contracts altogether terminated (Public Servant Dissolution Case 1992, 133-59). ${ }^{2}$

Public employees could be summarily dismissed under the terms of the Unity Treaty if they had violated the principles of humanity incorporated in the Universal Declaration of Human Rights or the International Covenant on Civil and Political Rights (Unity Treaty, attachment 1, ch. 19(A), para. $3(1)(5)(1))$. In the view of many West Germans, this would cover acts of political repression and even ordinary collaboration with the Ministry of State Security (Stasi). ${ }^{3}$ Under the Treaty, East German public servantsincluding judges, prosecutors, and law professors-were to be dismissed on these grounds and often over the objection that at the time they had been acting in accordance with GDR law. One important ground for dismissal would be participation in any decision rejecting a GDR citizen's application to leave the country or engaging in an act of reprisal against the applicant. Public servants would also be dismissed if they were discovered to have been card-carrying members of the ruling communist party (Sozialistische Einheitspartei [SED]). (Almost all the GDR's legal professionals had belonged to the SED.) German labor courts generally took the position that GDR citizens who had held important posts in the SED or had performed more than routine tasks for the Stasi could be barred from most positions in the reconstituted civil service (Quint 1997, 172-76).4

2. In an action challenging these dismissals, the Federal Constitutional Court sustained the validity of the Unity Treaty's general provisions calling for the dissolution of certain administrative units, but held that public servants in particularly difficult circumstances, especially pregnant women and mothers with small children, were constitutionally entitled to continued employment in the public service.

3. The Unity Treaty included a special section on the Stasi. See attachment 1 , ch. $19(\mathrm{~A})$, para. $3(1)(5)(2)$.

4. Whether public servants-judges and legal scholars among them-could be discharged for mere membership in the SED was the subject of yet another judgment of the Federal Constitutional Court. In reviewing lower-court decisions sustaining such dismissals, the court held that neither party membership, party office, nor ordinary collaboration with the state or the Stasi would by itself be a sufficient reason for automatically discharging persons from their public service positions (See Stasi Dismissal Case 1995, 140-57). 
Among the many civil servants who lost their jobs were legal scholars associated with state-run legal research institutes and professors in university "law sections" (Meador 1986, 53-59).5 Prior to unification, only the universities of Berlin, Leipzig, Halle, and Jena had law faculties, with Berlin's Humboldt University having been reserved mainly for the training of judges and prosecutors. The GDR regime had abolished the law faculties of other East German universities, such as Potsdam and Greifswald. When these faculties were reestablished in reunited Germany, they were staffed almost entirely by West Germans, many of them docents (a teaching rank below that of professor) eager to step into newly created Eastern professorships and so advance their careers far more quickly than would have been possible in the West.

\section{The Judiciary}

Reorganizing the GDR's judiciary was no less cataclysmic than remodeling the civil service and the universities. First, the entire judicial system was swept away and replaced by the FRG's system of specialized courtsordinary civil and criminal courts as well as separate hierarchies of administrative, fiscal, social, and labor courts-and more formalized procedures and traditions. Second, given the GDR's Marxist-Leninist oriented system of legal education, in which fields such as property, commercial, and administrative law were relatively unimportant, few East German judges seemed prepared to preside over the new courts. With the closing down of most GDR courts on October 3, 1990, nearly all of East Berlin's 150 judges were summarily suspended pending a full review of their political loyalty and professional credentials, while their pending caseloads were transferred to West Berlin's courts. The eastward extension of West Berlin's courts required the appointment of an additional 215 professional judges, totaling 1,307 in Berlin as a whole. With certain exceptions to be noted later, nearly all the new judges were West Germans. To the dismay of many East Berliners, who were beginning to feel that they were being colonized by the West, hundreds of Western-trained lawyers also took up positions in East Berlin, specializing in areas of law such as contract and tax, the sounds of which grated on the ears of good socialists.

East Germany's vast system of nonprofessional social courts, staffed by 300,000 lay judges engaged in mediating disputes in work places and residential areas, was also abolished when Germany reunited (Meador 1986,

5. Under various GDR educational reforms, "faculties" of law were replaced by "sections" that in turn were divided into "departments" based on subject matter. Humboldt University's Law Section included departments of criminal law, labor law, economic law, international law, agricultural cooperative and land law, and the theory of law and state. 
140-45; Richert 1983). ${ }^{6}$ This extensive system of lay judges was one reason for the GDR's small number of full-time practicing attorneys. In 1989, they barely numbered 600 in a nation of 16.7 million citizens, ${ }^{7}$ amounting to a ratio of 1 lawyer to 28,000 citizens, as opposed to the FRG's 1 practicing lawyer for every 1,000 citizens. East Germany, unlike the FRG, was not a litigious society (Markovits 1996, 2284). ${ }^{8}$ Social solidarity and collective harmony, as Professor Markovits points out, were more important than private advantage or individual autonomy. Private law and personal rights count for much more in the FRG, a reality reflected in the field of legal education, the structure of substantive law, and the organization of the judiciary.

\section{THE RESOCIALIZATION OF EAST GERMAN JUDGES}

Markovits spent most of the GDR's last 25 days in East Berlin's central courthouse viewing trials and looking for judges and other legal personnel willing to talk about their official duties, their images of themselves, the impending shutdown of their courts, and their chances of continuing their careers after reunification. She found the judicial corridors filled with an atmosphere of gloom and frustration: gloom because bags were being packed, legal guidebooks were being tossed into waste bins, some judges were abandoning their posts, and a system of socialist justice was coming to an abrupt end; frustration because many pending cases would not be finished in time to avoid the expense and uncertainty of new proceedings in the courts of the FRG.

\section{East Germany's Trial Process}

In these "last days"- the title of the book's first section-Markovits witnessed several trials in ordinary civil suits. As we view these proceedings through her eyes, we see serious and solicitous judges trying to keep mar-

6. They were not courts in any West German sense; rather, they were designed as alternative dispute resolution boards "to enforce socialist standards of behavior through education; it [was] not their primary purpose to settle disputes through an adversarial process." Lay judges were not new to East Germany; they have been a traditional feature of the German judiciary. In the FRG, as in the GDR, lay judges have long served alongside professional judges in the regular judiciary, especially criminal tribunals.

7. The figure of 600 refers to practitioners serving the general population. Other lawyers, known as Justitiar, served as in-house attorneys in state-run enterprises. They were engaged mainly in rendering advice to employers (i.e., state managers) and employees (Meador 1986, 146-47). In 1989, there were around 3,000 such lawyers in the GDR.

8. In her recent study of GDR lawyers, one based largely on her detailed analysis of court records in the city of Lüritz, a pseudonym, Markovits emphasizes that East Germans pursued actions in court far less often than West Germans. She also found that in 1979 lawyers represented only $15.3 \%$ of all civil litigants and a mere $5.6 \%$ of all criminal defendants. 
riages from breaking up, work out child custody agreements, bring about friendly settlements in disputes between citizens and the state, and preside over cases challenging the dismissal of employees under East Germany's Labor Code. Along the way, she interviewed several of the presiding judges, most of them women in midcareer, who willingly talked of their professional roles and public lives.

Given the values of socialism, we are not surprised at her finding that the judges saw themselves more as mediators than as referees. Their view of the judicial role contrasted sharply with the Western model: They preferred dialogue to argument, personal narrative to abstract reasoning, solidarity to conflict, social integration to efficiency, substantive justice to formal procedure, community welfare to individual rights, settlement to ongoing controversy, and compromise to a winner-take-all position. Reflecting the didactic character of the trial process, civil procedure was also found to be simpler than in West Germany; its object was social peace and instruction in how people should get along with their socialist neighbors. Much could be said in favor of these humane practices, and perhaps the GDR's judges had every right to expect some reconciliation between their values of solidarity and altruism and those of autonomy and competition prevailing in the West, but no such convergence seemed possible in the face of the GDR's sudden demise.

As noted earlier, Markovits has not ignored the darker side of the judicial process in the GDR. She tried hard to elicit reactions to frequent tales about judges who imposed punishments or abandoned trials in response to the demands of political officials. Her respondents, however, resisted suggestions that they could be induced to decide particular cases in given ways on instructions from political operatives. Markovits was told that state inspectors had reviewed the records of most courts and that conversations about particular cases had taken place between judges and party officials; nevertheless, she believed that on the whole, socialist judges exercised independent judgment, free of overt political influence.

Her respondents were well aware of the arbitrariness and injustices of certain judicial decrees but, as one of them allowed, lack of legal restraints in sensitive "political" areas had not infected her work as a judge presiding over ordinary civil and criminal cases. This seems plausible in a dual state where judicial practice in accordance with law coexisted with political control of the judiciary, as was the case in Nazi Germany (Fraenkel 1941). That respect for law was more than a marginal reality in the GDR seems implicit in Unity Treaty provisions retaining GDR laws and judicial decisions that were compatible with the rule of law and the Basic Law.

In a larger ideological sense, however, as Markovits's respondents were quick to concede, all law is ultimately political, a point well taken when law 
is viewed within a self-contained system such as capitalism or socialism. ${ }^{9}$ Moreover, these respondents betrayed little doubt, mistrust, or anxiety over the essential goodness of the socialist system of justice. Yet it seems improbable that East German judges did not now and then compromise their independence, as the evasive responses to the interviewer's more pointed questions about their roles would seem to suggest. For example, some judges and prosecutors seemed untroubled by the fact that persons who had legally applied to emigrate lost their jobs. Nor were they particularly disturbed by orders withdrawing the courts' right to hear appeals in labor cases contesting such firings. Nor did their concept of judicial independence bar membership or activity in the Communist Party.

The GDR's judges and prosecutors no less than its legal academicians moved in lockstep with the regime, and I have the impression, after "listening" to Markovits's respondents, that most of them lacked the intellectual independence that might have prompted them to rethink aspects of the system they served. Their acceptance of socialism was so complete that they were trapped by their unwillingness to imagine another way of organizing the life of law and society. They were the victims of a false consciousness, drugged by the belief that the system they served was basically beneficent, and that essential beneficence could not be challenged. In short, they could tolerate the sufferings of people who dared to question the system and even excuse the penalties against them as justly deserved.

\section{Vetting the Judiciary}

In any event, the screening of East German judges who wished to retain their judicial posts was inevitable and indeed required by the Unity Treaty. Some 360 GDR judges and prosecutors who applied for admission to Berlin's judiciary were examined by a judicial screening committee-a body consisting of judges and elected officials chosen by Berlin's parliament-in cooperation with the city-state's Senate Administration of Justice. A veto of an applicant by either of these bodies-a two-thirds vote was required for approval in the screening committee-would defeat his or her reemployment. There was of course grave doubt that Eastern-trained judges could measure up to the high standards of the FRG's legal system, for which reason all were required to enroll in retooling classes taught by Western judges, lawyers, and professors. ${ }^{10}$

9. Lest we forget, American critical legal studies scholars have often pointed to the inseparability of law and politics in American judicial decision making (Kelman 1987).

10. Professional judges in the GDR received their training in a special four-year course of Marxist-oriented study in East Berlin's Humboldt University. Judges were elected to their positions for five-year terms in constituencies under party control. Party affiliation and class identification appeared to be important criteria of selection (Meador 1986,136-37). By contrast, FRG judges are chosen for life (i.e., until the compulsory retirement age of 68 ), largely 
Equally serious-and problematical - was the issue of political suitability, in regard to which Markovits, to her dismay, was unable to extract from any Western overseer a clear statement of the criteria used in "determining who among the candidates is acceptable to the Rechtsstaat" (p. 140); accordingly, it seems, Berlin's Eastern prosecutors and judges were reduced to depending on the good will of their Western examiners. For some, the act of filling out questionnaires, answering questions about their past, facing tests of loyalty to the FRG, and being pronounced "fit" or "unfit" to remain members of the German judiciary would be a humiliating experience. Older judges would take early retirement rather than submit to this ordeal. Some examiners the author interviewed failed to treat their Eastern colleagues as equals, spoke of them with condescension and, as she notes, refused to regard them as "part of the rule-of-law community" (p. 144).

Eastern applicants who were otherwise professionally acceptable and willing to admit the shortcomings of socialist legality, manifesting the appropriate degree of contrition for their own "mistakes," and demonstrating in word or demeanor that they would faithfully serve the German Rechtsstaat, could probably count on-although they could never be sure ofreemployment as a judge or prosecutor. But if they stuck to their guns, exuded arrogance, defended the past, refused to recognize the errors of socialism, or voiced doubts about the FRG's system of justice, they were almost sure to be disqualified. They were decidedly out of a job if their records showed that they had issued arrest warrants for persons accused of certain border violations or handed down severe sentences for political crimes such as possessing subversive literature, suppressing opposition views, trying to flee the GDR, or maintaining contacts with West German institutions. Even applicants who defended their continued membership in the Party of Democratic Socialism (PDS)-successor to the old SED-would find employment unlikely in East Berlin's reorganized judiciary, notwithstanding the PDS's legitimacy under the Basic Law. With these "standards" operating, few GDR prosecutors or judges were in any position to succeed against their Western competitors for responsible positions in Berlin. What made the experience even more irritating-and unjust in Markovits's view-is that many of the applicants were not informed as to precisely why they were being rejected.

From the present account, it appears that few eastern applicants were given the benefit of any doubt. But, an unsympathetic reader might respond, why should they have been presumed blameless? As Markovits herself writes-and laments-the "post-Honecker reform government under Hans Modrow . . . had ordered the cleansing of all East German personnel files." Fearing a "witch-hunt" after reunification, East German judges, like

on the basis of merit and after having survived a rigorous six-year program of theoretical study and practical training and three additional years of service as an apprentice judge. 
other public servants, "followed the decree's invitation with a vengeance." As she adds, it seemed as though they "must have been motivated by the wish to facilitate new beginnings by erasing memories of a distasteful past" (p. 141). Thus, in screening Eastern applicants, Western examiners had little to go on except interviews, questionnaires, and available court records. And, we need to remember, the judiciary, far more than the ordinary public service, was the main engine of the communist legal system.

Still, as Peter Quint notes (1997, 184), "[r]etention of large numbers of judges from the east would be essential" if "proliferating disputes [such as those] over property questions arising from the Unity Treaty" were to be resolved quickly and equitably. As he reports, only $17 \%$ of the Eastern applicants for Berlin positions "were permitted to resume their work for a probationary period," whereas the approval rate in other East German Länder was between 41 and $63 \%$ of all applicants seeking to continue on in the judiciary (Quint 1997, 187). Markovits's interviews in Brandenburg also established the relative leniency of the vetting there compared to the roughshod approach in Berlin. The different treatment of holdover officials in East Berlin may have had something to do with trying to fit them into an existing government; in other East German Länder, where West Germans were fewer in number, the competition was not as intense. ${ }^{11}$

\section{DECONTAMINATING THE LEGAL ACADEMY}

Most of Markovits's diary entries focus on her interviews with legal scholars and her experience on the Humboldt law faculty's screening committee. We should, however, distinguish between legal scholars associated with non-university research institutes and those associated with universitybased faculties of law. These two groups were treated differently. As for the institutes, the Unity Treaty provided that they would be evaluated "to determine their academic merit and viability in a united Germany" (art. 38), the evaluation to be overseen by the FRG's independent and influential Science Council (Wissenschaftsrat). Recall that under the Unity Treaty, governmental units could be dissolved without apology if they were no longer needed or were unacceptable for academic or political reasons. Beyond the pale of acceptability were Potsdam-Babelsberg's Academy of Law and State and the Institute of State Security in Potsdam-Eiche. Both were unceremoniously dissolved, ${ }^{12}$ although several faculty members from the Babelsberg Academy were hired by Potsdam's new law faculty.

11. The harsh standards applied in Berlin might also be attributed to the "hard-nosed" leadership of Jutta Limbach, Berlin's seemingly unforgiving minister of justice, a Social Democrat who in 1994 was elected president of the Federal Constitutional Court, in part because of her aggressive campaign of judicial reform in Berlin's eastern sector.

12. Also dissolved, and on the Science Council's recommendation, was the GDR's Academy of Science, a centrally controlled research organization consisting of 24,000 schol- 


\section{Structuring the Process of Review}

Partially in response to the dissolution of these state-supported research institutes, several Eastern universities also embarked upon a campaign of dissolution and reform. Particularly controversial in Berlin's Humboldt University, as Markovits notes, was the dissolution of five academic departments considered beyond repair for ideological reasons and their subsequent reconstitution with new personnel. Peter Quint $(1997,179)$ writes that "the effect of 'dissolving' some faculties was 'in one blow' to replace eastern with western personnel-and, given the traditional gender structure of western faculties, it was also, in many cases, to replace women with men."

But could a university department be "dissolved" with the intention of rebuilding it with new staff from West Germany? Several Berlin professors challenged the legality of these dissolutions, ${ }^{13}$ charging that they violated treaty provisions requiring the individualized evaluation of persons employed by retained units or agencies. Berlin's Administrative Court of Appeals agreed: On June 6,1991, as Markovits reports, the court "stopped the closure of the Humboldt University's five 'politically tainted' faculties" (p. 165), a decision that relied on language in the Federal Constitutional Court's judgment of April 24, 1991. Even so, she feared that in "the long run" Berlin's Senate would "very likely do with Humboldt University as it pleases" (p. 166). Markovits's comment undoubtedly stems from her experience as part of the self-review process in Humboldt University's law faculty. In January 1991, at the urging of Rosemarie Will, dean of the Humboldt law faculty, she agreed to include her name on the ballot from which the reviewers would be selected. The faculty elected her as one of four internal professors to serve on an eleven-member committee that included four external members, all from the FRG. Dean Will, controversial in her own right because of her previous membership in the SED, thought that at least two Western scholars among the four internal members would "raise the

ars, academic assistants, and employees organized into disciplinary units, including a section on "law and the state." Some 500 of the Academy's scholars and employees whose jobs and departments were being terminated or reconstituted contested the decision in the Federal Constitutional Court. As in the Public Servant Dissolution case (1992, 133-60), the Court found that the procedures employed in dissolving or rebuilding various scientific institutes were necessary to bring research and science up to the traditional standards of academic governance and achievement in West Germany. But once again the Court invalidated the dismissal of pregnant women and new mothers. In addition, it extended the employment contracts of persons who had been given insufficient notice of their dismissal and thus little time to find alternative employment.

13. Quint writes, "But even after their Abwicklung [dissolution] in mid-winter 1990-91, the "dissolved" faculties did not actually suspend operation. Rather, newly appointed 'founding deans' from the west decided which former faculty members would be retained on interim short-term contracts, while the principal courses were often taught by visiting professors from the west. Permanent appointments were then made pursuant to the recommendations of an academic 'founding commission' under the leadership of the western 'founding dean'" (1997, 178). 
Committee's reputation in the eyes of distrustful West Berlin observers" (p. 112).

The committee's task, like that of other departmental investigating boards, was to assess the "professional competence" and "personal qualifications" of each member of the law faculty. Employees of the law department were permitted to retain their posts pending the review. Any person wishing to remain in the department's employ was required to appear before the committee. Its recommendations would then be submitted to the law department's faculty council. A negative decision could be appealed to the university's central review commission, which in turn received its mandate from Humboldt's academic council. The last word remained in the hands of Berlin's Senate Administration.

\section{Standards of Review}

Markovits found the committee's task both formidable and frustrating: formidable because the committee was given just a few weeks between January and March of 1991 to determine "who among 106 members of this oncesocialist university is suitable and deserving to continue to work in a cleansed and democratized academy" (p. 128); frustrating because, as with the vetting of judges, no criteria were set forth in advance of evaluating the "entire lifework" of these men and women. The committee relied on personal interviews, curricula vitae, and other information supplied by the candidates themselves, but its hearings took place within a general atmosphere of animosity and distrust. A not uncommon attitude was a West Berlin professor's admonition "against a repetition of that misplaced forgiveness which Germans once before displayed toward former Nazi functionaries" (p. 89). Others, including some Eastern reformers, advised a total housecleaning in which few if any of the current staff would be rehired. Ultimately defining its own mandate, the committee tried conscientiously to navigate between the shoals of sensitivity and bluntness. Fully recognizing the imperfect justice of its own efforts, Markovits ambivalently remarked, "May those whom we have done injustice forgive us" (p. 128).

In the end, the committee defined its mandate narrowly. It focused on "a person's ability and willingness to adjust to the demands of a bourgeois legal system" (p. 130). Committee members looked for evidence of personal integrity even while realizing that "legal scholarship and teaching [in the GDR] had played an important role in the law's corruption" (p. 131). It was therefore "right to focus our investigation on the question of whether erstwhile servants of the system could now plausibly be integrated into the new Rechtsstaat" (p. 131).

But how was that to be determined? In part, Markovits writes, by looking for "misuse[s] of political and intellectual authority" and also by requir- 
ing "the right mixture of guilty feelings and self-confidence," for "we became suspicious if someone too breezily identified with his former self" ( $p$. 137). The process was a hit-and-miss affair, and Markovits herself appears to have had doubts about the vetting procedure and perhaps even the validity of the committee on which she served so conscientiously and responsibly. "Why should two Wessis, coming from another world, and a number of colleagues whose lives and careers were just as much in shambles as their own," she asked, "now be in a position to select those who should be allowed to keep their jobs and those who should lose them? What legitimated us to make such life-shattering decisions?" (p. 133).

Even the formal legality of these committees has been questioned. Peter Quint observes that some of them "had no legal authority and, in the end, little influence." He writes that "most decisions on scholarly achievement were in essence made by western experts in accordance with traditional [western] criteria," and "even if the candidate fully satisfied the criteria of professional achievement and political suitability . . . there was still the question of whether there was a 'need' for the individual's work according to the plans of the newly structured university or institute" (Quint 1997, 179-80). By some estimates, no more than a fifth of the old faculty was retained in most reconstituted departments; nearly all the new hires were Western Germans.

\section{The Final Reckoning}

The committee on which Markovits sat found that 10 of 28 professors lacked "sufficient personal integrity" to remain on the law faculty (p. 136). Other Humboldt professors appear to have been rejected at higher levels of the review process, whereas some refused altogether to appear before the committee. Still, she tells us, "I do not see how we could have done our job better" (p. 138). Even her Eastern colleagues agreed that some sort of screening was necessary if GDR faculties were to be brought up to speed academically and the worst pockets of ideological encrustation removed. That this objective could not be achieved with surgical precision should not in my view count as an argument against the process itself. The procedures used by the committee appear to me less offensive than the wholesale attitude of some Western examiners that East Germans had little or nothing of value to contribute to the reform of the old GDR's legal academy.

What Markovits did find offensive-and in her view violative of the Basic Law's guarantees of equal protection and academic freedom-was a Berlin Senate statute that effectively "disenfranchise[d] East Berlin professors at the very moment in their history when they should learn to do free scholarship in a free society" (p. 195). Specifically, the statute barred East Berlin professors from voting on matters of university self-governance if 
they had not yet been reappointed under the new procedures laid down by their Western overseers. Accordingly, faculty members who rose to professorial rank under East German rules were relegated to second-class status, however "seriously committed [they might have been] to the search for scientific knowledge and insight." In defense of the law, one Berlin official interviewed by the author appeared to take the position that "Humboldt University professors are not scholars within the meaning of the Constitution" (p. 196). ${ }^{14}$

What was the final result in Humboldt University? The present diary, which ends abruptly in the summer of 1991, leaves the complete story untold. It may be remarked, however, that those professors and employees who received positive votes were not immediately dismissed, although many of them began to leave the University voluntarily. Of the former socialist professors on the law faculty, only four remained. Meanwhile, Berlin's minister of science rejected several of the persons selected to fill new chairs in the law faculty, three of whom were discovered to have had Stasi contacts, but two of these managed to sue their way back into the university. Many middle-level employees such as lecturers and assistants who were on limited contracts eventually left the university, while older employees were phased out with offers of early retirement. Finding it difficult to land other academic jobs, many took up the practice of law. ${ }^{15}$

\section{COMING TO TERMS WITH THE PAST}

Imperfect Justice is a sensitive and sensible account of the thoughts and experiences of East Germans jolted by a sudden political transition. By magnifying the sorrows and frustrations of particular persons in the East, and also by highlighting the snobbery and suspicions of many in the West, the diary captures a central reality of reunification in the old GDR. But not the whole reality; a diary such as this cannot be expected to emphasize the systemic disorders that paralyze and deform a body politic. And we should

14. Humboldt faculty members affected by the law filed a constitutional complaint against it in the Federal Constitutional Court. It was dismissed on procedural grounds.

15. These data are based on information Inga Markovits was kind enough to pass on to me in her letter of October 9, 1996. A similar story could be told of other Eastem German law faculties. The old law faculties of Halle, Jena, and Leipzig went through a rebuilding process not unlike Berlin's Humboldt University. Newly founded law faculties in Dresden, Frankfurt (am Oder), Greifswald, Potsdam, and Rostock universities were revived in partnership with western law faculties and under the direction of founding deans from the West. Dresden's experience was typical. Law professors from Freiburg, Heidelberg, Tübingen, and Mannheim volunteered to hold lectures in Dresden while a fresh, permanent faculty was being assembled and a new library founded and staffed. By 1994, 13 newly appointed professors from West Germany had replaced the temporary faculty. Only one professor-an employee from Dresden's former Institute of Licenses and Patent Law-was hired by the new faculty. For the details of the founding of the Dresden law faculty, see Fakultät für Rechtswissenschaft (no date). 
also bear in mind that Markovits's respondents were not ordinary folks; they were legal professionals, members of the SED, and part of the governing elite of an undemocratic and repressive political regime. As sorrowful as their personal stories have been, they were nonetheless responsible, at least in some measure, for the sins of the regime as a whole.

Even at the level of academic law, GDR professors had seriously compromised their independence. Markovits is on point in remarking that "legal scholarship and teaching [in the GDR] had played an important role in the law's corruption" (p. 131). She adds that academic law's defilement started with the "infamous Babelsberg conference" of 1958, when legal scholarship was placed in the service of both state and SED. "It is depressing," she writes, "to see how readily East Germany's legal academics who had just timidly begun to find their feet, played along in the vicious game" (p. 107). What she had to say about legal academics could as easily be said of judges and lawyers. "Even [their] abstract and harmless words," she reminds us, "can link to form a spider's web of intellectual conformity that may choke an entire political system" (p. 171).

What then does a democratically elected successor regime do with such persons? The respondents in the present diary have no blood on their hands; they are beyond the reach of criminal law, indeed of any legal process. Many were simply opportunists. At the very most, they may be said to have helped to spin the "spider's web" that choked the political system. But that is not a crime. Any attempt to charge them under some provision of West German law would go against the rule-of-law principle, nulla poena sine lege (no penalty without a law), and violate the Unity Treaty to boot. But should the GDR's legal professionals be held accountable in some other way? In the way of the "imperfect" vetting process, for example, that Markovits describes and the justice of which she often doubts?

Perhaps the question can be placed in perspective by turning briefly to some of the post-unification debates over the nature of the GDR's past (Torpey 1993, 7-20; Probst 1993, 21-33; McAdams 1993a, 49-60). One version of the past holds that East Germany was a virtual prison from which people could escape only at their peril and in which resistance was futile or impossible, generating an image of autocratic rulers holding sway over innocent and helpless subjects. Once liberated, the way to justice is to punish the "prison's" jailers. This vision seems to have driven the initial West German effort to prosecute the GDR's leaders and to hold ordinary soldiers responsible for using lethal means to stop persons from fleeing the country. Belying this interpretation, however, was the discovery that hundreds of thousands of ordinary citizens had cooperated with the regime in spying on their neighbors.

An opposing version of the past holds that almost everybody voluntarily went along with the regime because this was the only way to live a 
moderately acceptable and productive life in the GDR. In short, as Václav Havel said of his compatriots in Czechoslovakia, "everyone in his or her own way is both a victim and a supporter of the [old communist] system" $(1989,53) .{ }^{16}$ Since under this reasoning everybody collaborated with the regime to some extent, nobody can be singled out for special guilt except those found to have committed crimes or abused their offices in an egregious manner. This interpretation, also widely accepted in West Germany, evokes sympathy for ordinary East Germans and a willingness to "forget and forgive" their compromises and sins of omission. Again, this interpretation is reflected in the effort to apprehend and punish the most conspicuous violators of human rights.

Still another version, shared by many of the GDR's former communists and some of their Western supporters, envisions the old GDR as a bastion of anti-fascism that invited unsavory comparisons with the "creeping fascism" encouraged by West Germany's "formal bourgeois democracy." For many of East Germany's intellectuals who accepted this view, the GDR's militant communism contrasted sharply with what they regarded as the FRG's "halfhearted" effort to deal with Germany's Nazi past. They often recognized the deficiencies of the socialist state but nevertheless believed in its essential rectitude. Like many Western intellectuals writing on German affairs, they had accepted the reality and legitimacy of the GDR. Because they embraced its professed goals of justice, peace, and solidarity, they often muted their opposition to its oppressive practices and policies out of fear of alienating the SED and upsetting the spirit of détente between the two German states.

In the minds of East German dissidents responsible, at least in part, for the GDR's downfall, each of these versions distorts history. The dissidents and their politically progressive compeers reject any reconstruction of the past that would ignore the heroism, resistance, and basic decency of those East Germans who managed to live honorably in the GDR. They are inclined to view the "purge" that has taken place under largely Western auspices as "victor's justice" and one that lacks any "nuanced analysis of the past as a legacy of 'merit and mettle' as well as 'guilt and spinelessness"' (Torpey 1993, 13). They insist on fixing responsibility where it belongsmoral and political as well as legal-while incorporating East Germany's heritage of democracy and dissent into the political culture of united Germany.

The GDR reformers who engineered East Germany's velvet revolution-many of whom, incidentally, opposed reunification in the hope of democratizing the existing regime-viewed the Abwicklung's process and

16. With respect to East Germany, Jane Kramer reports, "The Stasi [i.e., the office of internal security and their secret informers] were everywhere, and, for all practical purposes, they were everybody. Every church had Stasi, and so did every farm, factory, hospital, school, and housing project, and every political party with honorary access to the Communist parliament" $(1996,164)$. 
vetting procedures described in Markovits's diary as a predominately Western effort to place the burden of the past entirely on the GDR and to relieve the FRG of any moral culpability for the condition of political servitude in which so many East Germans found themselves for so many years. To ignore the "good" side of the GDR's past-for example, its antifascism, enlightened humanism, and commitment to equality-they say, marginalizes those good people of the GDR who otherwise might have been expected to shape a more vigorous tradition of civic responsibility in Germany as a whole.

What is going on here is no less than a struggle over the "politics of memory." Any final declaration of moral and political-as opposed to criminal-guilt may well determine whose version of the past prevails. But no one version is likely to prevail. If the West German experience is any guide, "coming to terms" with the past-whatever that may mean to some people-will be a long-range project involving a rethinking of the causes for the postwar division of Germany and including a study of the policies that governed the relationship between the two German states in the following 40 years (McAdams 1993b). There is also the difficult question of who the GDR's authentic revolutionaries really were. The writers and other professionals who fled to the West over the years? Or those who remained behind in the hope of transforming the socialist state even as they cooperated with it? As for the latter, their cooperation may have been one condition of their capacity to reform the system or, barring that, to contribute to its humanization. Seen from this perspective, one can easily sympathize with the plight of many of the legal professionals that Markovits interviewed.

On the other hand, given the velocity of the constitutional changeover in the GDR, it is difficult to imagine a regime of corrective justice that could have measurably improved the processes that Markovits observed and recorded. For one thing, the process in Germany seemed more balanced than in either Poland or Czechoslovakia. The Czechs placed all former communists under a blanket five-year government employment ban, whereas the Poles imposed hardly any restrictions at all (Rosenberg 1995, 3-121). Markovits's diary shows that the Germans at least tried to individualize the process of finding "guilt" and "innocence." Overall, they made an honest effort to abide by rule-of-law principles in reviewing the records of East Germany's legal professionals. And when these principles were shamelessly ignored, or when dismissals from the public service resulted in extraordinary hardships on certain classes of employees, the Federal Constitutional Court stepped in to redress the wrong (Public Servant Dissolution Case; Judgment of February 21, 1995).17

17. More recently, the Federal Constitutional Court ruled against disbarring lawyers who had done no more than file periodic reports with the Stasi on conversations heard and activities reported in the course of their daily business (Bar Admission Case, 1995: 213-248). 
Far more disconcerting than the vetting process itself, in my view, was the arrogant and self-righteous attitude of many of Markovits's Western respondents. This attitude blinded them to the merits of the judicial practices she observed in socialist courtrooms. And who is to say whether West German lawyers and judges were better models of morality and justice than their East German colleagues? Were they any less political in their devotion to a capitalist legal order than were socialist legal professionals to their legal order? What is to be gained in comparative legal analysis by contrasting an ideal-type Western legal system with the empirical reality of a socialist system? If the socialist system had been assessed in terms of its ideals rather than behavior, perhaps the comparison between the legal orders of East and West Germany would have revealed fewer differences (Scheppele 1996). Saying this, however, is not by any means to suggest that the vetting procedures used in East Germany were inappropriate or unfair.

What then should be our final assessment of the "trials" and events witnessed in Berlin? A part of me sympathizes with Markovits's sensitive and charitable view of many of her respondents. Some were scoundrels, but others were upright and compassionate individuals dedicated to the common good as they saw it. Those who believed deeply in socialism and its values of solidarity and equality could be charged with no more than invincible ignorance, thus freeing them of moral responsibility for the Unrechtsstaat's misdeeds. Those who were vincibly ignorant and had now seen the light could also be excused because they were able and willing to make their own distinctive contribution to reunified Germany. Even more deserving of our sympathy are East German legal professionals who had not only opposed the injustices of the former GDR but who by their post-reunification behavior could be counted on to serve the FRG with diligence, commitment, and distinction.

With respect to the latter, Markovits has in mind persons such as Rosemarie Will, who with "energy and direction ... redesigned and staffed in one short and turbulent year [Humboldt University's law curriculum]" (p. 198). Ms. Will, however, has not given up those socialist values that she thinks could humanize the FRG's political economy as well as its legal system. Since the publication of Imperfect Justice, she has continued to advance professionally. She clerked for two years at the Federal Constitutional Court and was recently nominated to Brandenburg's constitutional tribunal. Her nomination, however, has triggered stiff opposition because of her prior membership in the SED and current sympathies for its successor, the PDS. Her opposition comes not only from Christian and Free Democrats but also from some Eastern Social Democrats who feel that she compromised herself by loyal and faithful service to the GDR (Frankfurter Allgemeine Zeitung 14 Sept. 1996, 4). Although the normal politics of judicial recruitment is at 
work here, many view it as unfair that her past-free of any hint of villainy or abuse of office-should continue to haunt her in the present.

On the other hand, part of me agrees with the skeptics. After all, the GDR's legal professionals represented and embraced a political order that subordinated the individual to the state. They also served a socioeconomic order that reduced people to little more than cogs in an enormous machine. East Germans may have had full employment and bread, but what is this to compare with the wounded and corrupted freedom that was the lot of most persons stripped of their dignity because they could not read, travel, or go to church for fear of losing privileges or risking imprisonment? What then is wrong with barring persons who profited from this system from holding positions of public responsibility and trust in a democratic Rechtsstaat? Bruce Ackerman, liberal constitutionalist that he is, even suggests that such persons may not be entitled to individualized faultfinding. "If service in a leadership position is established," he writes, "we know that the apparatchik has benefited from a system that oppressed the majority." He continues:

Since his past efforts at leadership led the country to economic and political catastrophe, why is it unfair to allow others to take leading positions in the new regime? Indeed, the group-oriented character of this strategy will even redound to the advantage of the discharged apparatchiks themselves. They will not suffer from the kind of stigma that typifies case-by-case faultfinding. Rather than ruining the reputations of individual officeholders, the proscription approach simply forces them to find their own way in the emerging market economy. $(1992,96)$.

Ackerman's counsel would seem to be a morally acceptable way of dealing with the GDR's legal professionals.

But in the special case of Germany, would such an approach foster the trust and confidence needed to build on the FRG's existing democracy? Those East Germans who took the risk of opposing the GDR regime, and also those who simply retained their personal integrity, need to know that they too belong to the new Germany. All former residents of the GDR willing to live and work under the sign of the Basic Law (Grundgesetz) must be made to feel that existing constitutional standards and rights apply to them as much as to any of their Western cousins. Needless to say, the integration of a prior dictatorial regime into a stable democracy is far from an easy process, and perfect justice in this situation is an end unlikely ever to be achieved. Perhaps the best that can be expected is imperfect justice, the hurts and woes of which Inga Markovits has described with such insight and candor. 


\section{REFERENCES}

Ackerman, Bruce. 1992. The Future of Liberal Revolution. New Haven and London: Yale University Press.

Fakultät für Rechtswissenschaft. No date. Festakt zu Gründung der Juristischen Fakultät: Technische Universität Dresden. Dresden: Technische Universität Dresden.

Fraenkel, Ernst. 1941. The Dual State. New York and London: Oxford University Press. Havel, Václav. 1989. Living the Truth, edited by Jan Vladislav. London: Faber and Faber. Kelman, Mark. 1987. Critical Legal Studies. Cambridge: Harvard University Press.

Kramer, Jane. 1996. The Politics of Memory. New York: Random House.

Markovits, Inga. 1971. Marriage and the State: A Comparative Look at East and West German Family Law. Stanford Law Review 24:116-99.

-1978. Socialist vs. Bourgeois Rights-An East-West German Comparison. University of. Chicago Law Review 45:612-36.

-1982. Law or Order-Constitutionalism and Legality in Eastern Europe. Stanford Law Review 34:513-613.

. 1986. Pursuing One's Rights Under Socialism. Stanford Law Review 38:689-761. 1996. Children of a Lesser God: GDR Lawyers in Post-Socialist Germany. Michigan Law Review 94:2270-2308.

McAdams, A. James. 1993a. Revisiting the Ostpolitik in the 1990's. German Politics and Society 30:49-60.

- 1993b. Germany Divided: From the Wall to Reunification. Princeton, N.J.: Princeton University Press.

Meador, John Daniel. 1986. Impressions of Law in East Germany. Charlottesville: University Press of Virginia.

Probst, Lothar. 1993. German Pasts, Germany's Future: Intellectual Controversies Since Reunification. German Politics and Society 30:21-33.

Scheppele, Kim Lane. 1996. The History of Normalcy: Rethinking Legal Autonomy and the Relative Dependence of Law at the End of the Soviet Empire. Law \& Society Review 30:627-50.

Quint, Peter E. 1997. The Imperfect Union: Constitutional Structures of German Unification Princeton, N.J.: Princeton University Press.

Richert, John P. 1983. West German Lay Judges. Tampa: University Presses of Florida.

Rosenberg, Tina. 1995. The Haunted Land: Facing Europe's Ghosts After Communism. New York: Vintage Books.

Torpey, John. 1993. The Post-Unification Left and the Appropriation of History. German Politics and Society 30:7-20.

\section{CASES}

Bar Admission Case, Judgment of August 9, 1995, 93 Entscheidungen des Bundesverfassungsgerichts (BVerfGE) 213 (1995).

Public Servant Disssolution Case, 84 BVerfGE 133 (1992).

Stasi Dismissal Case, 92 BVerfGE 140 (1995). 